\title{
Clinton emphasizes technology over science in choosing advisers for presidential campaign
}

Washington. If a man is known by the company he keeps, Bill Clinton, the Democratic candidate for president, could be the most science-orientated leader in US history. Clinton has not only picked as his running mate Senator Al Gore (Democrat, Tennessee), arguably the most technologically informed member of that body and the most enthusiastic for science, but he has dozens of prominent experts on hand helping him to make science and technology an important plank in his platform.

But, attentive as Clinton appears to be towards science and technology, it would be a mistake to assume that this will translate into more money for basic research. Like the candidate, the people around him are focused more on technology than on science. Not a single practising — or even former scientist is part of his inner circle.

Two influential figures are John Sculley and John Young, the presidents of Apple Computers and Hewlett-Packard, along with independent economic and business consultants Ira Magaziner and Tom Schneider. As a group, Clinton's advisers have focused on ways to strengthen the US economy, with science and technology a means to that end. When the candidate talks about shifting defence spending to the civilian sector and boosting the prominence of science and technology, what he really has in mind is developing products that will sell well.

Clinton's public statements reflect this concern about industry. He has advocated a civilian equivalent to the Defense Advanced Research Projects Agency to target and fund research aimed at important technologies and permanent tax credits for industrial research. National laboratories would set aside as much as 20 per cent of their budgets for joint projects with industry and a nationwide network of "technology extension" centres would help to transfer government research innovations to the private sector.

The people behind these ideas are better defined by their access to Clinton than their ideology. At the top of the list is Gore, whom Clinton has promised will serve as technology czar in his administration, coordinating government science and technology programmes much as Dan Quayle, the current vice president, has tried to reduce industry regulation as head of the White House Council of Competitiveness.

This is a natural role for Gore, whose interest in research issues is so great that some accused him of running for "national scientist", not president, during his failed attempt for the Democratic nomination in 1988. Gore is chairman of the science, technology and space subcommittee of the Senate Commerce, Science and Transportation
Committee and has held dozens of hearings on subjects ranging from global warming and the environment to supercomputers and space. His pet project has been a national high-performance computer network, a modern equivalent to the automotive highway programmes that his father, former Sen. Albert Gore Sr, promoted 30 years ago.

Apart from Gore, those closest to Clinton have little direct experience in science

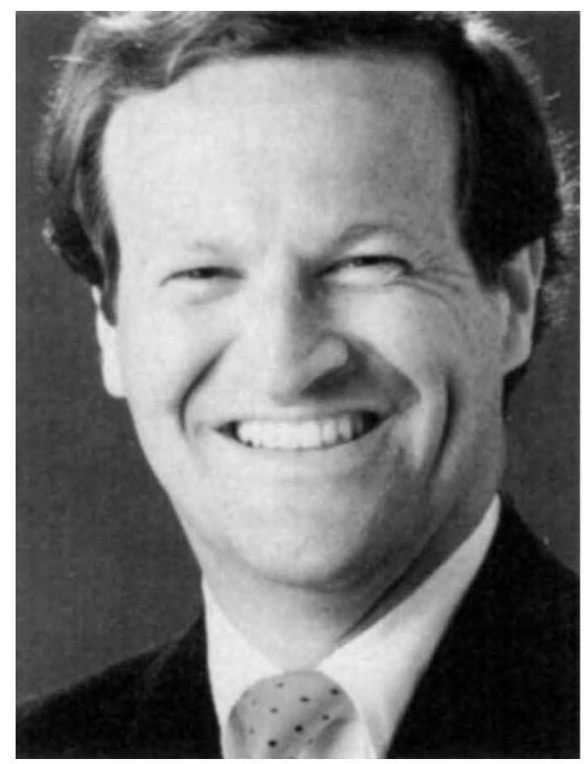

Schneider coordinates working group.

policy. Magaziner is president of SJS, Inc., a corporate policy consulting company based in Providence, Rhode Island, specializing in international industrial competition. His one notable foray into basic research is not his proudest moment: in April 1989 Magaziner failed to convince Congress to spend $\$ 25$ million to create a cold fusion research centre "before the Japanese do". As a Clinton adviser, Magaziner has concentrated on domestic economic policy, including research on 'strategic' technologies.

Schneider, a long-time friend of Clinton, is president of Restructuring Associates Inc., of Washington, DC, another corporate consulting company specializing in competitiveness. He is coordinating a loose-knit science and technology working group which has provided position papers for the campaign. Among those who have contributed to the group's recommendations are Sculley, Young and members of the private Council on Competitiveness (unrelated to the White House office of the same name), including Erich Bloch, the former director of the National Science Foundation (NSF).

It is hard to find a working scientist who has shaped Clinton's thinking. A number of researchers, including Alexander Rich, a Massachusetts Institute of Technology molecular biologist, have contributed position papers on science issues, but their impact appears slight. The campaign's only statement on basic academic research, released on 12 October, assures scientists that "every dollar we cut from unnecessary defence spending will be redirected back into our university and research community." But it does not specifically mention basic research, and some of Clinton's previous statements - including a sketchy offer to increase research spending by decreasing overhead payments to universities - suggest that he has not spent much time on research issues.

One group hoping to change that is a collection of some 60 researchers, mostly physicists, known as the Council of Scientists and Engineers for Clinton-Gore. The group, organized by Marvin Goldberger, former president of the California Institute of Technology and the Institute for Advanced Studies in Princeton, has yet to meet or issue a policy document, but it plans to focus on science education, the significance of academic research and the need for increased government funding on science. "We're concerned that Clinton is overlooking the importance of basic research", says Goldberger, now at the University of California, Los Angeles.

Although the campaign has so far refused to get into the details of how a Clinton administration would be organized, outside advisers are already working on transition plans. One is William Wells, who until last year was chief of staff for D. Allan Bromley, the current White House science advisor. Wells and others want to make the science advisor a cabinet-level position, equivalent to the president's national security advisor. Another advocate of a stronger science adviser is Richard Bradshaw, a former NSF official who is working with Schneider.

Despite Clinton's outsider image, many of his science policy positions are already Washington staples. The importance of industrially-orientated research, a favourite topic of Walter Massey's, the NSF director, is "very much in line with the Clinton administration's goals", says Bradshaw, and not far from the type of arguments that Bromley made, without success, to his Republican peers. "A lot of our policy [recommendations] come from programmes that were abandoned or underfunded by the Bush administration", he adds. Clinton may portray himself as an agent of change, but his science policy reflects trends that are already well underway. If he wins next month, their pace can only accelerate.

Christopher Anderson 